\title{
Jurnal Bestuur
}

\author{
Vol.7, Issue.1, Agustus, 2019 \\ P-ISSN 2302-3783 \\ This work is licensed under a Creative Commons Attribution 4.o International License (cc-by)
}

\section{Economic Law Creation Beautiful Global Indonesia}

\author{
Liana Endah Susanti \\ Faculty of Law, Universitas Soerjo Ngawi - Indonesia. \\ Email Coresponden: endahliana112@gmail.com
}

\begin{abstract}
Indonesia is the world 's largest archipelago with 1,904,569 $\mathrm{km} 2$ of surface area. A very diverse landscape with a variety of abundance of flora and fauna is a special attraction for foreign tourists. Not only that, the natural wealth in Indonesia 's intestines is also very abundant, as are various minerals and richness from other mining materials. However, a abundance of skilled human capital, both in terms of science and technology mastered, do not complement the plentiful natural resources. This is one of the reasons superpowers should be providing cooperation. PT. PT. Freeport is an clear example of Indonesia 's collaboration in the mining sector with foreign parties. The first contract for Freeport-Indonesia was established in 1967. After the Foreign Investment Law was passed in 1967, Freeport became the first foreign mining firm to operate in Indonesia. But the existence of this partnership was regretted by many because it was perceived to be detrimental to the region. The reason is that so far nobody knows for sure how much gold and silver has been produced from the mining to date. The magnitude of the distribution of mining goods is also not quite good given that Indonesia owns land which is turned into gold fields. There are, in fact, many reports uncovering miserable stories of discrimination by indigenous people around the mining region. Justice is once again present as something that is not only wishful thinking, but also noble values that have to be realized for the collective good of the state goals set out in the Pancasila points and the preamble to the Constitution of 1945.
\end{abstract}

Keywords: Mining, PT. Freeport, Discrimination, justice

\section{INTRODUCTION}

Freeport McMoran Indonesia (Freeport) via the Grasberg mine, is the world's largest gold mining business. Freeport Indonesia has explored the 1967 Erstberg mine and the Grasberg mine in the Copper Pura area, Mimika Regency, Papua Province, in two places in Papua since 1988. While Mining International calls Freeport the world's largest gold mine, it is not inherently in line with the conditions of the people on earth who contribute to the world their natural resources. Discrimination and various intimidation cases often arise from elements pointing to the Freeport name. Moreover, all Freeport mining wealth outcomes in the form of gold, silver, copper, molybdenum, and rhenium are not yet known where the hiding is located. The facilities and benefits as well as the benefits enjoyed by Freeport officials amount to 1 million times Timika, Papua's population's annual income, which is only about $\$ 132$ / year. This means that the benefits that Freeport has obtained do not give birth to prosperity for Indonesia , particularly local residents.

The difference in colonial style is the seed of Papua 's conflict. Aside from occurring to the community, inevitably occurring problems are landscape 
damage and pollution from waste. Permanent damage experienced by residents is inversely proportional to Freeport 's motto, which dedicates its devotion to sustainable development and the advancement of world civilisation. Another bad possibility is not just a myth, given that it is said that this parasitic partnership will end in 2041. Waking up from what has befallen ignorance and the big name of PT is fitting for Indonesia. Freeport is a subtle means of colonization. It's not just about the nation's honor but also about the dignity and purpose of building a prosperous Indonesia. Moreover, the law on economic development must also be directed as it should, not only in accordance with the regime of the past which then trapped our nation in backwardness.

In essence, mining is part or all of the phases of mineral or coal research, management and exploitation activities that include general investigations, exploration, feasibility studies, construction , mining, processing and refining, transportation and sales, and post-mining activities. PT carried out the operation. Freeport is forecast to be Indonesia's largest mining company in the world. The Papua region is a place where Indonesia presents the wealth buried within the belly of Mimika Regency's Tembagapura highlands.

We have given up on PT at least 2.27 billion tons of ore, consisting of 1.02 per cent copper, 0.83 grams per ton of gold and 4.32 grams per ton of silver. In That Power. Meanwhile, based on data from the Energy and Mineral Resources Ministry (ESDM), output from these reserves reaches 109.5 million tons of ore per year, with a mine life of 23.5 years. Then what the Mimika community is getting is a big question mark for thinking people. Coupled with the magnitude of mining outcomes which rumors have recently grown.

Divestment accomplished by Indonesia by 51 per cent by PT acquisition. Inalum (Persero) is considered to be still lacking in compensation for the dignity of the local people who died in their own land before foreigners. Local governments are no longer seen as having jurisdiction in their own areas to settle disputes, instead providing reasons that the decision depends on the central government. Conversely, PT. Freeport believes the things that it promised were realized. The central government rejects the notion that the Papuans, especially the Amungme in Mimika Regency, are ignoring the people. They have claimed the procedures and laws of the economics of development to run as they should.

Papua is not ruled out, they are left behind. So we have to approach it, welcome it and then encourage them to step together. They need equity in Indonesia's education, health, social and law, because they need air, water, and food to live. Their bad story is just a way of asking them, as the way they are expressed is different from the intellectuals and that's what we need to fix.

\section{Results}

\section{The Rise of Different Conflicts and Separatism in Papua}

Most agency and separatist party conflicts between 1998 and 2015 occurred in highland locations such as Puncak Jaya Regency, Jayawijaya Regency, Jayapura City, Paniai Regency, and Lanny Jaya Regency, from records by the Coordinating Ministry for PMK and The Habibie Center. Initially, these conflicts were suspected 
on account of social and political discrimination, marginalization, economic development failure, and various other causes that exist in Papua.

Hundreds of lives were lost as a result of separatist activities carried out by armed groups in Papua. Beginning with the local community 's basic internal issues, to the case of a uprising that took many victims and even officials. The belief that victims are being reciprocated and that lives are being reciprocated with lives is a real thing that happens on our paradise planet. Their nationalism also means maintaining the tribal good name and honor, that's where branching comes from the form of nationalism against Indonesia itself. A situation within the situation is more accurately called Papua. Very delicate conditions require special attention, not just solutions to the surface. The economic and social climate in Papua is in dire need of improvement, not only for the containment of educational, health, and infrastructure facilities, but also for someone to be able to understand how people who are thick with adat live, so that all the rules and policies that the government does in vain are later.

Indonesia ranked 62nd out of 140 countries in terms of infrastructure development in the 2015-2016 Global Competitiveness Report, compiled by the World Economic Forum ( WEF). The ranking is kept at an acceptable level but in the Indonesian economy, it creates many big problems. Indonesia seems to have reached a more difficult level than merely procuring infrastructure in remote areas. Law No. 2 of 2012 on Land Procurement for Public Interest Growth, which is intended to facilitate the purchase of land from land rights holders, has recently been introduced. A new problem arises, however, because the local community does not accept the law that requires them to surrender (sell) their land, although the community does not intend to sell it. This is exacerbated by the only compensation offered on the property in the form of money which would undoubtedly make it difficult for local residents to find new places to live. In addition, the tribal structure in the Papua region which is still very dense makes it difficult for them to live apart from their tribe.

The polemic will become even more so if some people in the tribe do not accept it, which will then make people in the tribe provoked to perform anarchist acts. Within the tribe it is their idealism about nationalism that is very influential in defending the land they own. Portraits of events like this which are considered discrimination according to local Papuans. The impact of their idealism is the case of attacks on the infrastructure development workers. Because tribal customs and life are still held fast and affect the mindset of people even far away from civilization modernization.

The separatist movement carried out by the Free Papua Movement (OPM) and a series of related events that occurred in Papua were the result of Dutch upbringing that would at any time explode. The separatist movement that occurred in Papua is interesting to be examined for several reasons, including:

a. Papua is currently the only province in Indonesia whose integration process is through an international mechanism by determining the popular consultation (PEPERA). 
b. The separatist movement in Papua shows the combined character of the traditional understanding of the tribes with the symbolization of worship of the koreri or the Morning Star on the one hand, and on the other hand led by people who are educated in a modern ideology of nationhood to carry out dignified political lobbies.

c. The separatist movement in Papua lasted a long time and was always able to renew its leadership.

Even people affected by procurement often complain about the failure of their promises to what happened, slightly ahead of procurement. Just take the example of road or bridge construction, the quality of its presentation is considered extremely alarming. The amount of damage was considered to be an sign of misappropriation of the funds only after some time. And if this may happen due to Papua 's natural state and the state of the land there. Many other negative things that are becoming indicators of confusion and anticipated discrepancies. That is what needs evaluation in order to be further established.

Another important issue is nature resource discovery in Papua. Whether we make it happen or not, PT. Freeport has a major impact on local Papuan people's lives. New cases emerged by using the term Freeport, one after another. Freeport's misguided government trust in discovering Papua 's land is the reason local communities claim government guaranteed rights, and welfare is the most complicated. The predominance in the mining process of people from outside of Papua and even foreign citizens (foreigners) is very complained. It is hard for Papuans who are expected to contribute to the world's riches to find jobs in their own country. Owing to the waste dumped into the river, the loss of their crops and sago fields causes them to transform their brains. While their creative economy development capacity still needs empowerment.

Such complicated challenges, which are very difficult to find a bright spot, make it a little difficult for the people of Papua to move forward as they still live in the area Local Papuans can not if only "built a market" then "told to sell" without understanding what they are supposed to trade in. A decent living is not only about compensation, but also the direction in which to equate their way of living. Nevertheless, nature is no longer friendly given what happened because of the waste from Freeport, which includes a lot of tailings. Next is about the actions of people who are members of the army. A lot of reports from military leaders about coercion, bigotry and fear are suspected as the cause of the attack. Fair or not, there is a need to watch out for public attention and the facts to look for to prevent such events. Of course, to prevent protracted early hostilities between Papua and the Stability Guard for State security.

\section{Tackling Problems Relating to Economic Development and Other Problems Relating to PT Activities}

Local Papuans' concerns about school distance, lack of health facilities, their inaccessibility from the government and the challenge of getting food on television broadcasts may be very familiar to us. Never mind electricity, it's very simple the road to the building they call the house is very annoying to pass. This is our 
Indonesia, which is said to be the richest nation, but which enriches none. Though not all, it is always felt by those who are far from the "western" paradise world.

Coherence between the government's will and the capacity of local communities is often a difficult to surpass barrier. Indonesia is wealthy but its people's welfare is just a discourse. This is perhaps a figure that sounds a bit ironic but true. Regardless of what happens, who, how and why this happens, it seems hard to answer if we know Papua 's life only from the mass media news. Recalling the appearance of the river Ajkwa decades ago, and comparing the situation with other rivers around the PT mining area. Today's freeport is a true, big irony. Then how can the group become just gold scavengers that drift alongside PT. Freeport needs a very complicated answer, too. Those with enough capital and ideas could turn their livelihoods into merchants, motorcycle taxi drivers or even barbers. And it's very possible that migrants, not indigenous people, occupy those jobs.

Where are the Papuans of native origin?" is a simple question. And the answer is they chose to alienate themselves from the migrants who were being displaced from their homes. The decision is wise and a policy of those who still adhere to too thick a culture. In his book entitled "Kamoro Aspects of Original Culture," Ulianus Coenen OFM, Kamoro people are communities which put their moral principles into balance. Balance is important for them in living together to avoid catastrophes. So the title of this discussion is not incorrect, if I identify Papua as "Indonesia with a Foreign Taste." They admit that they are Indonesian but if they have to follow the Indonesian government's rules and ideas, there is a "alienation" (comprehension).

In a viewpoint that is even somewhat ridiculous for urban people, items that can be considered idealistic, metaphysical, political or some other classification are what cause paralysis on our golden planet. There's a hard line they keep teretorial, there's a need to build their special relationship with nature and there are souls they glorify between rocks and trees. Papua's industrialisation here is not incorrect, but for those who inhabited it before the stranger it is important to make a right assumption.

Recently, the growth of Papua 's economy, infrastructure, and culture has become a major country initiative. But the subjects themselves, namely the people of Papuan, felt it was too hard to strand them to the other side. This is not about how 2012 Law No. 2 was made by President Susilo Bambang Yudoyono And not how current leaders in government encourage sustainable development of infrastructure to embellish the region. But this is about how to prepare those who are far from worthy to be invited into world civilization (especially Papua). The thing to remember is that the Constitution of 1945 isn't just a complement to state identity. There's 4th Alenia opening that the government may begin to forget. There is article 27 paragraph 2, up to article 34 which the local Papuan community may not even understand how to read it. Furthermore Pancasila was generated with 5 items, and would not be complete without each item's function. 


\section{Conclusion}

Causes of conflict and separatism that occurred in the Papua region include, First, tribal nationalism that has been developing since colonial times, resulting in strife-filled local Papuans and anarchist acts. Secondly, empathy, idealism, ideology or any other types they use as guides frequently contribute to agitation on the part of their community who is offended or is insulted. Third, the ongoing revolution in the economic development of the government that is not accompanied by approaches and education adds to the turbidity of the situation and the lack of local people employed at PT. There's no question that Freeport and its displacement by civil society and even foreigners make them want to prove their presence. Yet often, the act of addressing using military procedure makes matters worse.

\section{References}

Leirissa, R.Z. 1992.“sejarah Proses Integrasi Irian Jaya”

Adzkia, Aghnia. "Meredam Konflik Berdarah di Papua” 10 April 2018 https://beritagar.id/artikel/berita/meredam-konflik-berdarah-di-Papua

Arumingtyas, Lusiana. "Kementerian Lingkungan Permasalahkan Penanganan Limbah B3 Freeport di Mimika" 31 Mei 2018 http://www.mongabay.co.id/2018/05/31/kementerian-lingkungan-permasalahkanpenanganan-limbah-b3-Freeport -di-mimika/

Asdhiana, I Made. “Timika Satu Kota Tiga Rupa” 24 Oktober 2013 https://travel.kompas.com/read/2013/10/24/1316474/Timika.Satu.Kota.Tiga.Rupa

Fatonah, Tinwarotul. "Kemelut Freeport, Inilah Kronologi Sepak Terjang Kontrak di Indonesia hingga Kasus Papa Minta Saham!”. Rabu, 22 Frebruari 2017 http://wow.tribunnews.com/2017/02/22/kronologi-sepak-terjang-kontrak-Freeport-diIndonesia-dan-kasus-papa-minta-saham?

Leirissa, R.Z. 1992.“sejarah Proses Integrasi Irian Jaya”

Wicaksono, Eko Pebrianto. "Ini Sisa Kandungan Tambang Freeport” 11 Nopember 2015 https://www.liputan6.com/bisnis/read/2362735/ini-sisa-kandungan-tambang-Freeport

Handayani, I.G.K.R., Martanto, R., Karjoko, L., Kadir Jaelani, A., Mukhlishin, “Application of advance data protection system as an efforts to improve Indonesia digital economy", International Journal of Advanced Science and Technology, Volume 29, Number 4, (2020) pp. 1774-1778.

Martanto, R., Handayani, I.G.A.K.R., "Classification of Sustainable Food Agricultural Land for Food Security in Bali, Indonesia”, Talent Development and Excellence, Volume 12, Number 2, (2020) pp. 1275-1281.

Khisni, A., Handayani, I.G.K.R., "The Transformation Of Islamic Law Into The National Legislation", Talent Development and Excellence, Volume 12, Number 2, (2020), pp. 1275-1281

Kusriyah, S., Handayani, I.G.A.K.R., "Embodiments Of The Principles Of Democracy In The Formation Of Legislation In Indonesia”, Talent Development and Excellence, Volume 12, Number 2, (2020), pp. $1275-1281$

Jaelani, A.K., Handayani, I.G.A.K.R., Karjoko, L., "The Political Law Of The Constitutional Court In Canceling The Concept Of The Four Pillars As An Pancasila As The State Foundation", Talent Development and Excellence, Volume 12, Number 2 (2020), pp. 1314-1321.

Jaelani, A.K., Handayani, I.G.A.K.R., Karjoko, L., "Development of Halal Tourism Destinations in the Era of Regional Autonomy in West Nusa Tenggara Province", International Journal of Innovation, Creativity and Change, Volume 12, Number 12, (2020), pp. 765-774. 
Handayani, I.G.A.K.R.Karjoko, L.Prasetio, Rachmi Handayani, I.G.K., Karjoko, L., Sudarwanto, A.S., "Dilemma In The Implementation Of Business Judgment Rule In Commercial Transactions Of StateOwned Enterprises" Talent Development and Excellence, Volume 12, Number 2 (2020), pp. 15411549

Karjoko, L., Winarno, D.W., Rosidah, Z.N., Handayani, I.G.A.K.R., "Spatial Planning Dysfunction In East Kalimantan To Support Green Economy", International Journal of Innovation, Creativity and Change, Volume 11, Number 8, (2020), pp. 259-269.

Najicha, F.U., Handayani, I.G.A.K.R., Hartiwiningsih, Waluyo, Pramugar, R.N., "The Construction of Law System in the Field of Environmental Governance in Realizing Justice and Green Legislation in Indonesia", International Journal of Psychosocial Rehabilitation, Volume 24 Number 7 (2020).

Jainah, Z.O., Handayani, I.G.A.K.R., "Religious Terrorism", International Journal of Advanced Science and Technology, Volume 28, Number 20 (2020), pp. 500-506 